\title{
A enunciação religiosa e a palavra para autoafir- mação da fé na sociedade
}

Religious enunciation and the word for self-assertion of faith in society

\section{La enunciación religiosa y la palabra para la autoafirmación} de la fe en la sociedad

Paulo Sérgio Raposo da Silva Universidade Federal do Rio Grande do Norte (Brasil)

LATOUR, Bruno. Júbilo ou os tormentos do discurso religioso. São Paulo: UNESP, 2020.

No livro Júbilo ou os tormentos do discurso religioso, o renomado antropólogo e filósofo das ciências, o francês Bruno Latour, desenvolve uma abordagem original acerca dos tradicionais conflitos entre ciência e religião no sentido de demonstrar como essas narrativas se imbricam no que tange à linguagem e modos de comunicar suas proposições. Deixa claro que conteúdo e forma são elementos que se complementam, de sorte que os saberes científicos precisam enfrentar as dificuldades ainda têm em relação à religião enquanto conceito e acerca de como interpretar suas enunciações. Por sua vez, essas enunciações religiosas também enfrentam problemas para se afirmar, de modo que quem se debruce sobre o tema precisa ter em mente que há, e deve haver, de um campo e de outro, um amplo leque de possibilidades conceituais que desautorizem análises apressadas ou que se contente com as tensões históricas há muito conhecidas.

Diferentemente da norma, a obra não possui sumário e divisões convencionais por capítulos; é composta, no entanto, por seções temáticas que se intercomunicam, devidamente intituladas no canto superior direito das páginas. Essas seções temáticas vão desde questões linguísticas até dificuldades sociológicas de afirmação dos movimentos religiosos e a difícil relação entre o mundo secularizado e os discursos de fé. A palavra e aquilo que o autor chama de "os profissionais da palavra", os clérigos, ganham centralidade nas discussões 
propostas e nas complicações oriundas do trato descuidado de qualquer texto sagrado. Embora discorra sobre questões metodológicas da pesquisa e investigação, Latour esclarece que seu interesse não é pensar naqueles que falam sobre religião, mas sim nos que falam religiosamente.

Uma vez compreendido o dinamismo dessa fala, um conjunto de características das institucionalidades e das experimentações pessoais de cada sujeito com a sua maneira de crer e professar sua fé podem vir à tona e permitir ao observador, tal como aos próprios fiéis, descrever-se com um pouco mais de nitidez.

Fica evidente que, para abordar esses assuntos, o escritor perpassa por conceitos caros ao universo dos debates das questões religiosas, tais como o agnosticismo, ateísmo e fundamentalismo, apesar de sua preocupação não se voltar para esses movimentos. Volta-se precisamente para os efeitos da forma de comunicação entre crédulos e incrédulos. Seu foco é descobrir como, em meio a circunstâncias adversas de ordem sociocultural, seria possível validar ideias, interesses e ideologias substancialmente religiosas.

Nesse sentido, aliás, as conclusões a que Latour chega podem ser consideradas polêmicas, principalmente por abalarem as pressupostas inerrâncias das doutrinas dos mundos das religiões, afinal, defende o autor, mentira e elaboração são constitutivas do processo de autoafirmação das crenças que sempre precisam alterar seus rituais, seus enunciados e suas propostas específicas para continuar a pregar a verdade no presente. Essa elasticidade, esse relativo afastamento do que antes era inegociável, essas mudanças e alterações que são capazes de retirar textos do contexto para aplicações que, do ponto de vista tradicional das religiosidades, não seriam adequadas, redundam inevitavelmente na torção das palavras venerandas para algo atual, que confundem descendentes e novos fieis enquanto gravitam em um conjunto de distorções que promovem outras modalidades de leitura.

Portanto, mais do que um mero exercício hermenêutico do vocabulário de origem cristã em particular e religioso de modo geral, consagrados no mundo ocidental, Latour discute as dinâmicas epistemológicas que dizem respeito muito mais ao lugar dos religiosos no mundo moderno do que aos seus investigadores. Isso torna sua proposta ainda mais intrigante, porque, ao falar prioritariamente sobre as articulações de quem discursa religiosamente, Bruno Latour apresenta as estratégias retóricas dos fiéis para se afirmarem em 
uma sociedade neoliberal e materialista. Para o autor, ao contrário do que se faz em outras áreas do conhecimento em que é possível inovar, descobrir, influir sobre o objeto estudado, a abordagem da religião, enquanto fenômeno, demanda certa fidelidade às circunscrições das próprias experiências religiosas postas em perspectiva.

Dessa maneira, as controversas entre o método científico clássico e essa proposta de análise das religiões do antropólogo podem ser vistas além dos impasses históricos fartamente conhecidos e debatidos. Não basta mais decidir como equacionar as diferenças de interpretação dos fatos existentes entre as religiosidades e as ciências naturais e sociais, mas sim elaborar uma maneira própria de lidar com a religião que não se limite aos auspícios do fazer científico tradicional sem, obviamente, abrir mão do rigor, da objetividade e da clareza.

Para Bruno Latour, agradar ou desagradar crentes ou ateus não deve ser o horizonte de quem de fato se preocupa com um discurso interpretativo que trate lealmente o fenômeno das dificuldades da inserção religiosa no mundo tal como se apresentam. O desafio é ainda mais nobre e maior: ao discernir as traduções e as linguagens religiosas, bem como as palavras repetidas ao longo dos séculos, cabe discutir e avançar no debate até que ponto as adequações, nuances e as estratégias epistemológicas e político-sociais que essas formas de expressão encontram para permanecer circulando são capazes de redesenhar feições, determinar novos percursos e refazer práticas rituais de fé daqueles que, estando vivos, são os herdeiros da crença e dão continuidade ao que o antropólogo chama de "comunhão dos santos".

Há séculos, o grande problema desses movimentos linguísticos e hermenêuticos da religiosidade, atada ao texto, fica sob a responsabilidade dos "profissionais da palavra" que, convivendo com um mundo classificado por Latour como odiável por aqueles profissionais, precisam encontrar as palavras certas para contrapor os ídolos, o modernismo, o consumismo, o sexo, a democracia. Nunca foi fácil, porque, assevera o antropólogo francês, o mecanismo religioso faz com que muitos passem a cambalear e impor obstáculos, o que torna um trabalho extenso encontrar a fala certa, o termo exato, o discurso mais ajustado ao que se quer descrever, definir ou perpetuar.

É preciso, pois, resistir às unificações conceituais e vocabulares feitas às pressas. É também necessário prestar atenção ao léxico de que se dispõe 
para aferir se esse léxico descreve o que dizem as religiões com o mínimo de coerência e verossimilhança e, sobretudo, o que se faz a partir dessas palavras. Os tormentos provenientes da tarefa pertencem aos que creem e aos que não creem.

Mestrando Paulo Sérgio Raposo da Silva Universidade Federal do Rio Grande do Norte (Brasil) Programa de Pós-Graduação em Educação Grupo de Estudos da Complexidade (GRECOM) Orcid id: https: / / orcid.org/0000-0003-3558-3448 E-mail: pauloraposo10@gmail.com

Recebido 28 jul. 2020

Aceito 6 ago. 2020 